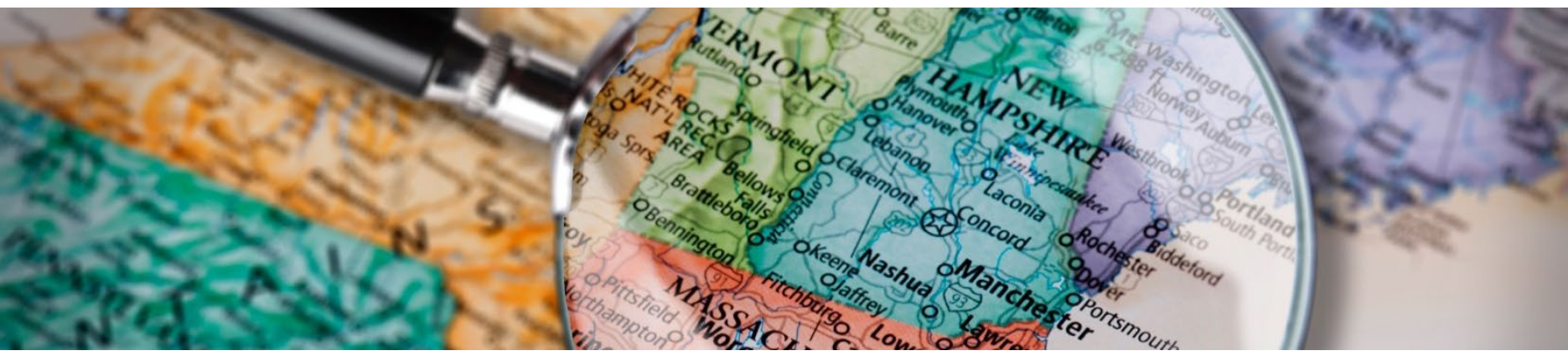

Regional Brief | 2019-02 | July 16, 2019

\title{
Aging and Declining Populations in Northern New England: Is There a Role for Immigration? \\ Key Facts
}

\section{Riley Sullivan}

\section{Summary}

In hundreds of communities across northern New England, the population is aging rapidly and becoming smaller. The entire country is aging, but northern New England stands out: Among the populations of all US states, those of Maine, New Hampshire, and Vermont have the top-three highest median ages, respectively. The situation is even more extreme in northern New England's rural counties, where the populations of the smallest towns generally are substantially older than those of the rest of the region. These communities also have seen the

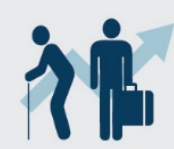

The ratio of senior residents to working-age residents grew in 93 percent of northern New England's cities and towns between 1990 and 2017.

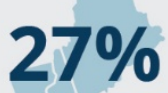

Twenty-seven percent of all cities and towns in northern New England lost population during this period.

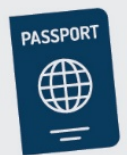

Immigration accounted for a substantial portion of the population growth, particularly in towns with the smallest gains in native-born population.

slowest, or even negative, population growth over the last three decades. As the populations of the rural regions become older and smaller, policymakers are concerned about the ability of the local communities to maintain their labor force, sustain local businesses and the tax base, and provide care for the growing number of senior residents. This regional brief explores changes in the size and age of the populations of the cities and towns in the three northern New England states. It also considers the role immigration plays in sustaining the stability and growth of those populations. 
Regional Brief | 2019-02 | Aging and Declining Populations in Northern New England: Is There a Role for Immigration?

\section{Economic Impacts of Population Aging and Decline}

Population aging and population decline each carry a range of implications for a city or town. A local population decline depletes the available workforce, diminishes the tax base, weakens the health of the business environment and the housing market, and destabilizes institutions such as schools and hospitals. ${ }^{1}$ An aging population also has negative consequences for the workforce and tax base, and it poses unique demands on public services. $^{2}$

The loss of working-age residents (aged 18 to 64), in particular, has both direct and indirect consequences for a community's workforce and tax base. In the short term, it results in smaller per capita output. ${ }^{3}$ In the longer run, when prime-age residents leave a community, they take their children and their reproductive potential with them, exacerbating the negative effect of their out-migration on the population size and age structure. Because of this generational effect, net out-migration of young adults contributes to a cumulative process of population decline and aging. ${ }^{4}$

A shrinking supply of working-age residents can prompt employers to look elsewhere to expand their business, which makes it more difficult for local governments to collect enough tax revenue to pay for infrastructure and education. An inferior infrastructure and school system, in turn, can encourage the younger people who had remained in the region to head elsewhere for more opportunity. This can cascade into further problems by making the region a less attractive destination for migration. ${ }^{5}$ Cities and towns with a declining population also are likely to see decreases in the number of establishments that provide financial services, education, and leisure and hospitality activities. Declining student enrollment, resulting from a decrease in the size of the school-age population, can deprive schools of resources and make it difficult to remain open. An increase in the median age of the population also is shown to have the effect of decreasing residents' access to services, even when the community's population doesn't decline. ${ }^{6}$

\section{The Geography of Population Growth and Decline in Northern New England Towns}

Each northern New England state (Maine, New Hampshire, and Vermont) experienced overall population growth between 1990 and 2017, but the growth was unevenly distributed: The population of the larger metropolitan areas expanded the most, while many rural areas saw their population decline. Slow population growth-and in some areas, population loss-has garnered significant attention across northern New England. $7,8,9$ Figure 1 illustrates the changes in population across municipalities over this period. ${ }^{10}$ Twenty-seven percent of the cities and towns across Maine, New Hampshire, and Vermont lost population between 1990 and 2017, and an additional 44 percent saw their population grow at a rate that was less than the national average of 30.2 percent. In one-third of the cities and towns, the number of residents aged 18 to 64 declined. These shrinking populations are located primarily in southern Vermont, northern New Hampshire, and all across Maine, with the exceptions of the Portland and Bangor 
Regional Brief | 2019-02 | Aging and Declining Populations in Northern New England: Is There a Role for Immigration?

areas. Most of the cities and towns that kept pace with or exceeded the national population-growth rate are located in southeast New Hampshire, coastal Maine, and the Burlington, Vermont, area.

Local populations can decline through internal migration-when fewer people move into a city or town than move out. However, the greatest source of population change in New England since the 1990s has been the drop-off in "natural population increase," which is the number of births less the number of deaths. ${ }^{11}$ Birth rates have fallen and mortality rates have risen as the population has aged. The declining birth rate results not only in slower overall population growth, but also in the even faster aging of an already relatively old population.

\section{Figure 1: Percent Change in Population}

Northern New England States, 1990 to 2017
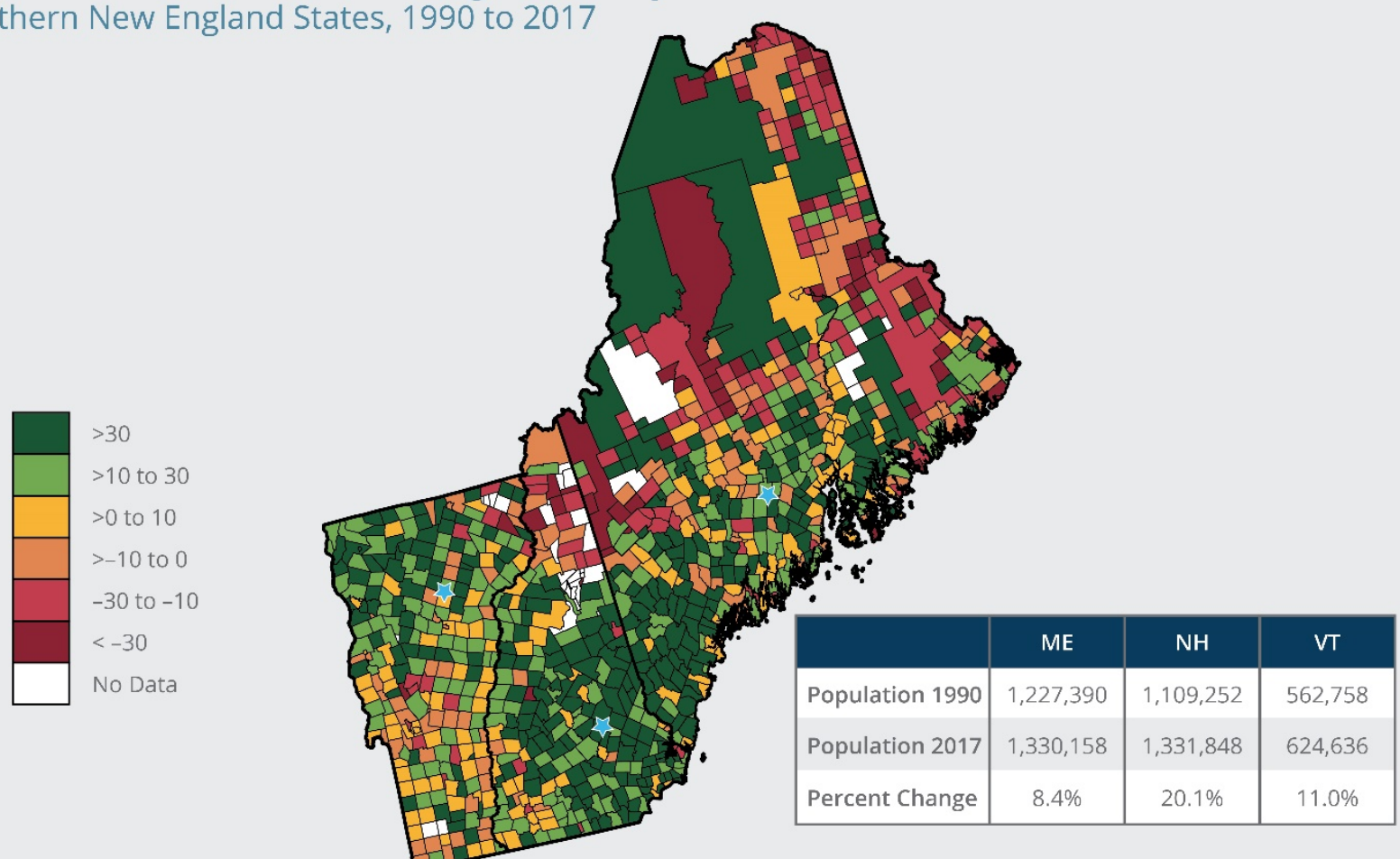

Sources: US Census Bureau 1990 Decennial Census and US Census Bureau American Community Survey, 2013-2017.

\section{Aging Population and the Dependency Ratio}

In 2017, the median ages in Maine (44.7), New Hampshire (43.1), and Vermont (42.9) were the first, second, and third highest in the country, respectively. Maine is projected to have more residents aged 65 or older than residents under the age of 18 by 2020, which is 15 years earlier than the entire country is expected to hit that benchmark, according to 
Regional Brief | 2019-02 | Aging and Declining Populations in Northern New England: Is There a Role for Immigration?

a 2018 report by the US Census Bureau. ${ }^{12}$ By 2030, 28 percent of Maine's population will be 65 or older-up from just 16 percent in 2010; no other state's population will have a higher share of older residents. ${ }^{13}$ Across the country, only 20 percent of the population will be in this age group. At 17.7 percent in 2017, the share of senior residents in Vermont's population was already close to the projected national figure for $2030 .{ }^{14}$

As the median ages and projections suggest, the 65-or-older share of each northern New England state's population is among the highest in the nation. The "dependency ratio" is commonly used to assess the sustainability of public services, which are most heavily focused on school-age children and seniors. The ratio measures the number of dependents (residents under the age of 18 and 65 or older) in a population divided by the number of working-age residents (aged 18 to 64) in that population. The assumption is that the working-age population economically supports the entire population. Between 1990 and 2017, the dependency ratio increased in 54 percent of the cities and towns of Maine, New Hampshire, and Vermont.

A decrease in the size of the youngest segment of the population can cause the standard dependency ratio to mask more substantial shifts in an area's demographic composition. The "old-age dependency ratio" takes this factor into account. This measure is derived by dividing the number of residents who are 65 or older by the number who are 18 to 64. Between 1990 and 2017, 93 percent of the cities and towns across Maine, New Hampshire, and Vermont saw an increase in their old-age dependency ratio.

Table 1 compares the age profiles of northern New England cities and towns with the rest of the country in 2017. Nationally, 22.6 percent of the population was under the age of 18 , and 15.6 percent was 65 or older. Relative to the national averages, nearly half of the northern New England cities and towns-a combined total of 495 municipalities from the three states - had both a smaller share of residents under the age of 18 and a greater share over 64 . These communities tend to be smaller than average for northern New England and account for just over 31 percent of the region's total population.

The collective population of these communities with a relatively large number of senior residents and small number of younger residents has grown much more slowly than those of the other northern New England municipalities, expanding just 5.2 percent between 1990 and 2017 compared with a region-wide average growth rate of 13.4 percent over the same period. Towns with smaller working-age-population shares may experience many of the economic challenges described in Section II. They are not located in the parts of the region that have experienced exceptional growth in recent years, such as southern New Hampshire and the areas around Burlington, Vermont, and Portland, Maine. Some of the towns with disproportionately older populations, however, have experienced overall population growth. These include, most notably, communities along the coast of Maine and in northern Vermont that have become increasingly popular retirement destinations. ${ }^{15}$ The most rapidly growing cities and towns in northern New England, however, are those with a relatively small senior population and an averagesized or relatively large youth population-the four cells in the upper-right-hand portion of Table 1. 


\section{Table 1: Towns, Population Growth, and Immigrant Contribution by Age and Composition}

Northern New England States, 2017

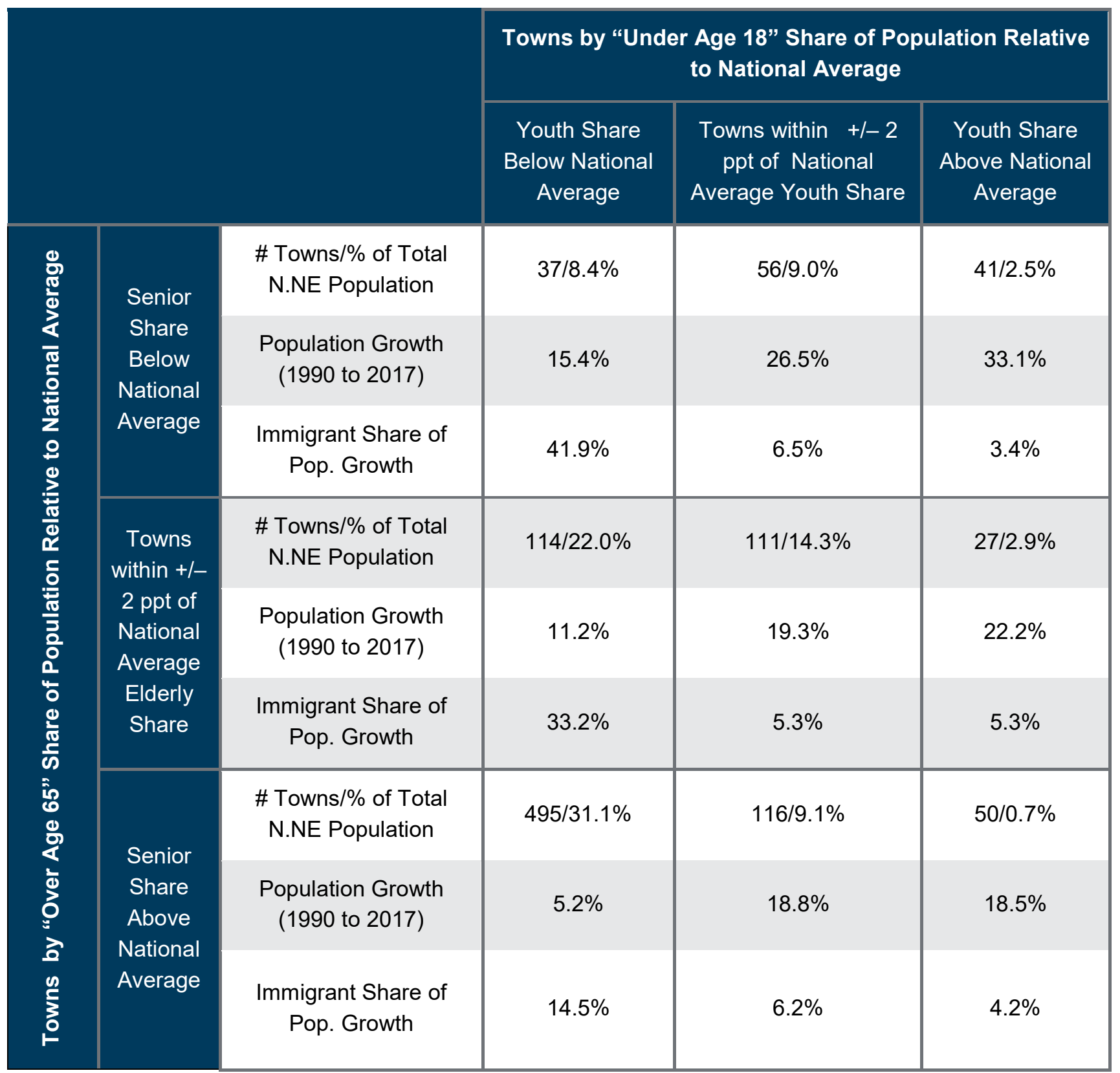

Sources: US Census Bureau 1990 Decennial Census and US Census Bureau American Community Survey, 2013-2017. 
Regional Brief | 2019-02 | Aging and Declining Populations in Northern New England: Is There a Role for Immigration?

\section{Immigration's Contribution to Growth in Slow-growing Cities and Towns}

Immigrants account for a fairly small share of the overall population in northern New England-less than 5 percent in 2017-but they have made a substantial contribution to the region's population growth in recent years. Between 1990 and 2017, Maine, New Hampshire, and Vermont together added nearly 60,000 immigrants, a growth rate of 63 percent, while the size of the native-born population increased by less than 12 percent. In seven of ten recent years (2009 through 2018), New England's population would have shrunk or failed to grow without the addition of immigrants. As natural increase continues to decline, immigration is expected to become the primary contributor to national population growth after $2030 .{ }^{16}$

\section{Table 2: Northern New England Population Composition and Change by Nativity}

\section{Northern New England States, 1990 to 2017}

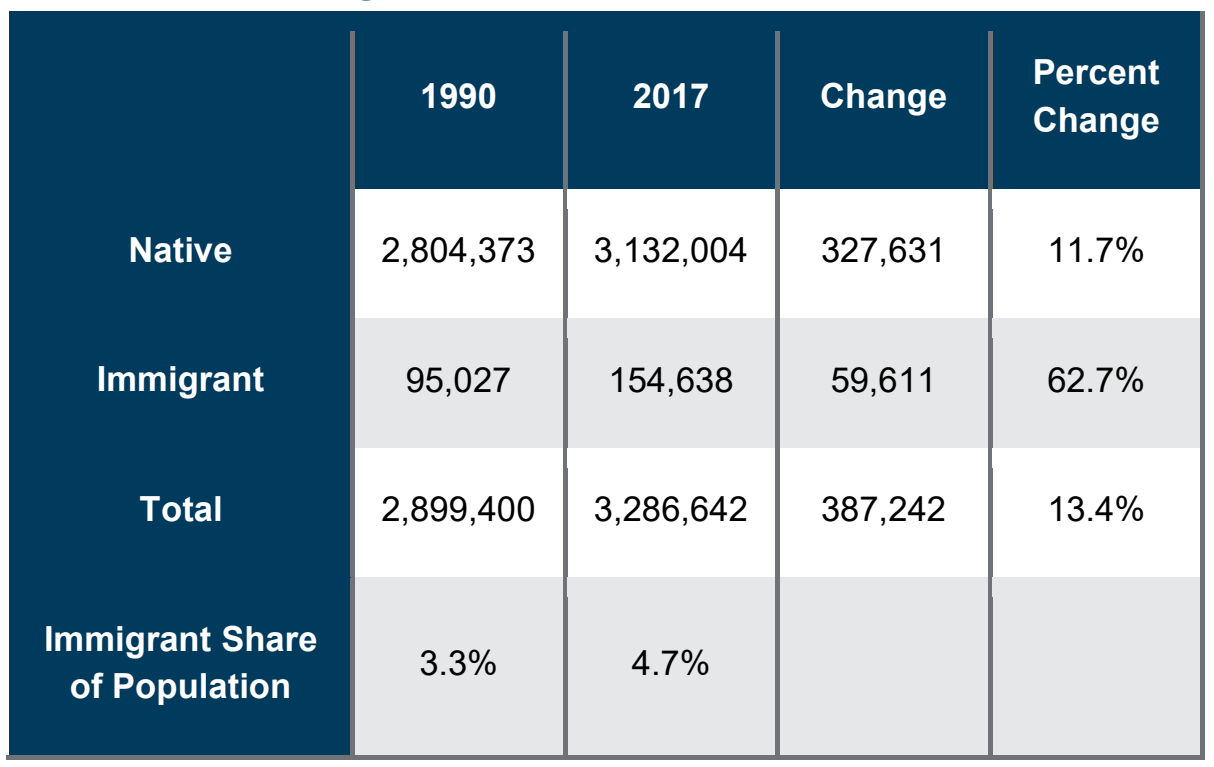

Sources: US Census Bureau 1990 Decennial Census and US Census Bureau American Community Survey, 2013-2017.

Immigrants help to not only buoy the overall population, but also to maintain age balance, because they tend to have more children than do native-born US residents, and they are younger. ${ }^{17}$ If immigrants flocked only to cities with young and growing populations, their addition would do little to counteract the population aging and decline experienced in rural communities. However, an analysis of the northern New England population data by city and town suggests that immigration makes a proportionally larger 
Regional Brief | 2019-02 | Aging and Declining Populations in Northern New England: Is There a Role for Immigration?

contribution to growth in the municipalities where the population is older and more-slowly growing.

The faster-growing, younger cities and towns identified in Table 1 have been the least reliant on immigration to support their growth, which was a combined 23 percent between 1990 and 2017. It accounted for just 5 percent of the total population growth in these communities. ${ }^{18} \mathrm{In}$ communities with a relatively small youth population (the first column in Table 1), immigration accounted for 29.2 percent of all population growth. For communities with both a small senior population and a small youth population, immigration accounted for more than 40 percent of growth.

When we sort towns by rate of native-born population growth between 1990 and 2017, we also see that increasing the immigrant population makes a particularly important contribution to the growth of slower-growing cities and towns (Figure 2, Panel A). The towns that were shrinking-municipalities in the bottom quintile of native-born growth saw their population decline by 11.5 percent on average-had their population losses modestly offset by an increase in the size of their immigrant population. (Examples include Calais, Maine, and Brattleboro, Vermont). ${ }^{19}$ Cities and towns in the second-lowest native-born-growth quintile (including Nashua, New Hampshire, and Rutland, Vermont) experienced the strongest impact from immigration. It accounted for nearly 60 percent of

\section{Figure 2: Immigrant Population Growth by Native-Born Population Growth}

\section{Northern New England States, 1990 to 2017}

Panel A: Immigration Contribution to Growth

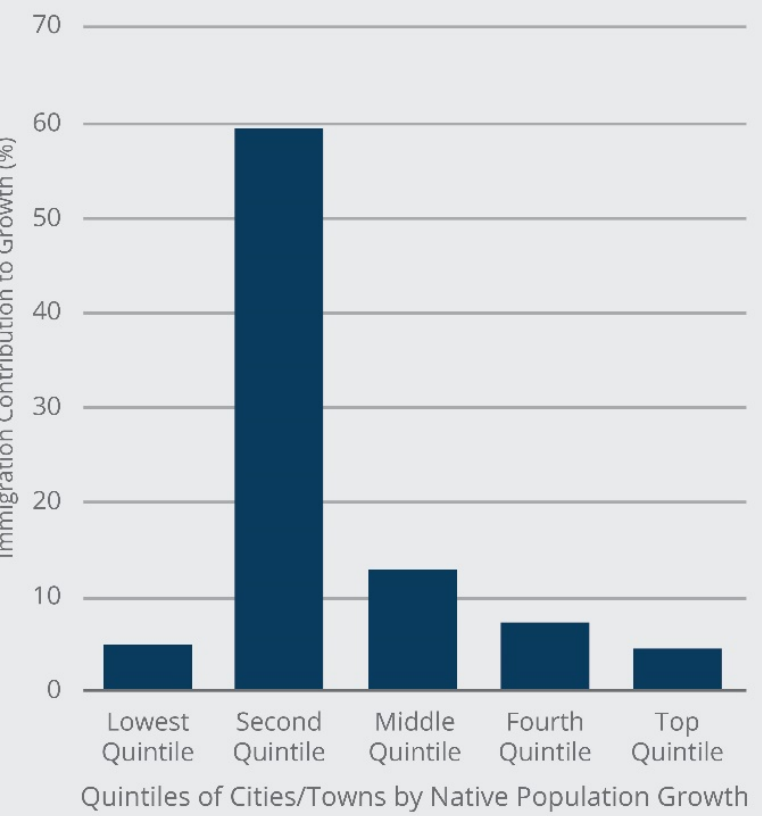

Panel B: Share of Total Immigration Growth

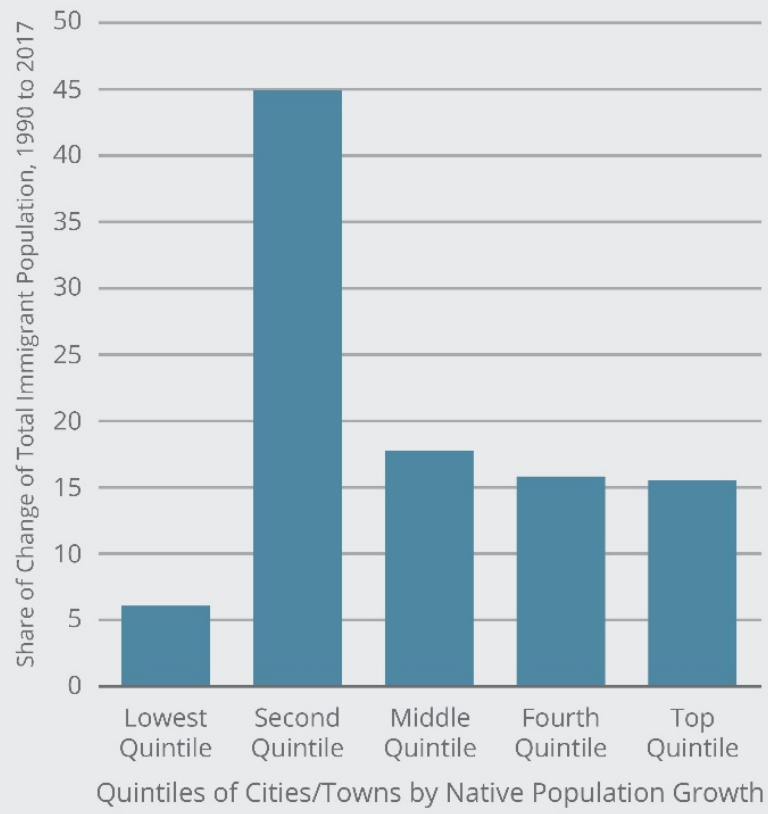

Note: Cities and towns with fewer than 500 residents in 1990 were excluded from this analysis

Source: US Census Bureau 1990 Decennial Census and US Census Bureau American Community Survey, 2013-2017 
Regional Brief | 2019-02 | Aging and Declining Populations in Northern New England: Is There a Role for Immigration?

the total population growth in these municipalities between 1990 and 2017. The middle quintile of towns, which collectively grew by 14 percent, attributed more than 10 percent of that growth to immigration. Immigration accounted for a fairly small portion of the growth in the cities and towns with the greatest native-born growth. (Figure 2 includes only towns with at least 500 residents in $1990 .{ }^{20}$ )

The same communities where immigration made the largest contribution to the rate of population growth (Panel A) also accounted for the largest share of total immigrant population growth in northern New England (Panel B). The second-lowest quintile of towns by native-population growth became home to 45 percent of the immigrants who settled in Maine, New Hampshire, and Vermont over the 1990-2017 period (Panel B). The top two quintiles of cities and towns with the greatest native-born growth each became home to approximately 15 percent of the region's new immigrants during this period, while the municipalities with the lowest native-born growth became home to just 6 percent of the new-immigrant population.

\section{Concluding Thoughts}

The population decline and dramatic aging taking place in cities and towns across northern New England have real, long-term consequences. Northern New England, even more so than the rest of the country, depends increasingly on immigration to sustain population growth in the face of a declining birth rate. The town-level analysis in this brief suggests that immigrants who have come to the region in recent decades have not joined just the larger, younger, and thriving communities; they also have settled in smaller towns and contributed to the growth of the population in those municipalities.

Increased levels of immigration, though not currently part of the federal policy conversation, could help to slow if not stop population decline in northern New England. A related policy issue is refugee resettlement. Cities in the state of New York have been able to stem population loss through refugee resettlement programs. Recent reductions in the number of refugees admitted annually into the country have been criticized for impeding the resurgence of these cities. ${ }^{21}$ Municipal officials in Portland, Maine, which is not experiencing population decline or aging, recently stressed the importance of allocating adequate federal resources for the refugee-resettlement process, so that it does not place undue burden on the host communities. ${ }^{22}$

Municipalities in other regions experiencing population decline have explored various incentive-based policies to alter the demographic trends. A number of very small towns throughout the Midwest offer newcomers free land if they are willing to build a home on that land and live there. ${ }^{23}$ Buffalo, New York, and Gary, Indiana, are among the cities trying to spur population growth by selling vacant houses for just $\$ 1$. The programs include occupancy requirements to ensure that the buyers reside in the communities. ${ }^{24}$ In 2018 , Vermont rolled out a program that provides as much as $\$ 10,000$ to people who relocate to the state but retain their current job and work remotely. ${ }^{25}$

It is unclear how effective these incentive-based approaches will be in disrupting population loss in small towns. At the national level, however, shuffling members of the 
Regional Brief | 2019-02 | Aging and Declining Populations in Northern New England: Is There a Role for Immigration?

working-age population between states is a zero-sum game. If the flow of immigration is reduced or limited, which seems to be the trajectory of current national policy, the demographic vise that is squeezing rural towns across northern New England will become even tighter, and policymakers will have limited options for responding.

\title{
About the Author
}

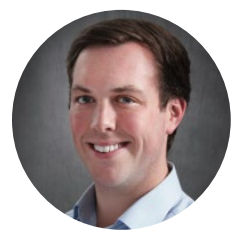

\author{
Riley Sullivan
}

Riley Sullivan is a senior policy analyst with the New England Public Policy Center. His research interests include income inequality and urban and regional economics. Sullivan is also the editor of New England Economic Indicators, a Federal Reserve Bank of Boston regional data resource. He earned his master's degree in public policy from Georgetown University and his BA in history from Boston College.

Riley.Sullivan@bos.frb.org

\section{Data Sources}

Steven Manson, Jonathan Schroeder, David Van Riper, and Steven Ruggles. IPUMS National Historical Geographic Information System: Version 13.0 [Database].

Minneapolis, MN: University of Minnesota. 2018.

The data used in this report are from the US Census Bureau's American Community Survey 5-Year Estimates 2013-2017 and the US Census Bureau 1990 Decennial Census. The geography considered is county subdivisions, which include cities, towns, and unincorporated areas. 


\section{Endnotes}

1 Ozimek, Adam, Kenan Fikri, and John Lettieri. April 2019. "From Managing Decline to Building the Future: Could a Heartland Visa Help Struggling Regions?" Economic Innovation Group.

2 Gist, John. 2011. "Fiscal Implications of Population Aging." In Handbook of Aging and the Social Sciences, 7th Edition, edited by Robert H. Binstock and Linda K. George, 353-366. Cambridge, MA: Academic Press. 3 Lim Rogers, Diane, Eric Toder, and Landon Jones. 2000. "Economic Consequences of an Aging Population," Urban Institute, Retirement Project Occasional Paper Number 6.

4 Johnson, Kenneth. 2011. "The Continuing Incidence of Natural Decrease in American Counties." Rural Sociology 76(1): 74-100.

5 Irwin, Neil, "America's Biggest Economic Challenge May Be Demographic Decline," New York Times, April 3, 2019.

6 Thiede, Brian, David L. Brown, Scott R. Sanders, Nina Glasgow, and Laszlo J. Kulcsar. 2017. "A

Demographic Deficit? Local Population Aging and Access to Services in Rural America, 1990-2010." Rural Sociology 82(1): 44-74.

7 Valira, Lori, "Maine Projected To Have More Old than Young People by 2020," Bangor Daily News, March 14, 2018.

8 "Editorial: NH's Aging Population Poses Serious Challenge," Seacoast Online, February 14, 2018.

9 Woolf, Art, "Vermont Aging Faster than Rest of US," Burlington Free Press, July 21, 2016.

10 The 2017 population estimates are derived from the American Community Survey, 2013-2017. In this report, analysis that uses percent changes is limited to cities and towns that had more than 500 residents in 2017. This cutoff eliminates large percent changes due to only a few people being within the margins of error of the ACS sampling frame.

11 Nelson, Peter B., "Patterns of Demographic Change across New England," presented May 6, 2019, at the Lincoln Institute of Land Policy, Cambridge, MA.

12 Vespa, Jonathan, David M. Armstrong, and Lauren Medina. 2018. "Demographic Turning Points for the United States: Population Projections or 2020 and 2060." US Census Bureau. March 2018.

13 Valira, Lori, "Maine Projected To Have More Old than Young People by 2020," Bangor Daily News, March 14, 2018.

14 Woolf, Art, "VT's Median Age Is Nearly 5 Years Older than Nation's," Burlington Free Press, July 25, 2018.

15 Canfield, Clarke, "Retirees Now Head to Unexpected Places—Such as Maine," Bangor Daily News,

September 17, 2012; Carter, Shawn M., "Vermont Was 'The Most Popular State to Move to' Last Year, Study Says-Here's Why," CNBC, February 5, 2019.

16 Frey, William H. "US Population Growth Hits 80-year Low, Capping off a Year of Demographic Stagnation," Brookings Institution, The Avenue, December 21, 2018.

17 Khazan, Olga, “Immigration Is the Only Reason the US Doesn't Have an Aging Crisis," The Atlantic, January 30, 2014.

18 Immigration's contribution to population growth is defined here as the difference between the growth rate of the total population and the growth rate of the native-born population.

19 The native-population growth rates was -14.1 percent for the first quintile, 4 percent for the second, 14.6 percent for the third, 26.6 percent for the fourth, and 50.5 percent for the fifth.

20 The analysis in Figure 2 is limited to the 772 cities and towns that had more than 500 residents in 1990; in small towns with few non-native residents, small fluctuations in the number of foreign-born residents can appear much more substantial than they actually are.

21 Goldbaum, Christina, "Luring Refugees: N.Y. Cities Desperate for People Try a New Strategy," New York Times, May 13, 2019.

22 Billings, Randy, "More Asylum Seekers Arrive in Portland from Southern Border as City Debates

Assistance," Portland Press Herald, May 6, 2019.

23 Murphy, Kevin, "Midwest Towns Cannot Give Land Away to Modern Homesteaders," Reuters, March 31, 2012.

24 Bendix, Aria, "Cities across the US Are Selling Abandoned Homes for \$1, and It's a Sign That the Wealth Gap Is Getting Worse," Business Insider, April 29, 2019.

25 Salam, Maya, "Move to Vermont. Work from Home. Get \$10,000. (Or at Least Something.)," New York Times, June 1, 2018. 